\title{
Treating Stroke From Inside the Blood Vessel
}

\section{Time Matters}

Steven Karceski, MD

Neurology ${ }^{\circledR}$ 2021;97:e2250-e2252. doi:10.1212/WNL.0000000000012920

\section{How Endovascular Therapy Helps Patients With Stroke}

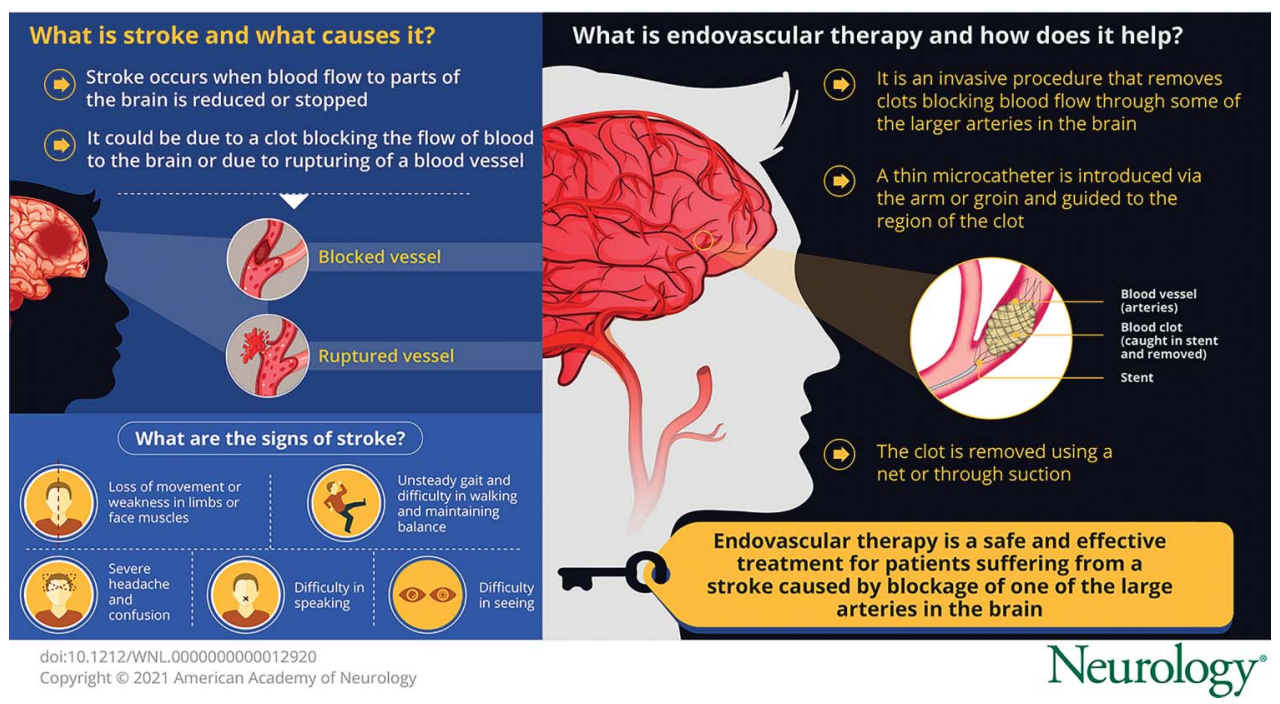

Related Article

Association

Between Time to

Endovascular

Therapy and

Outcomes in

Patients With

Acute Basilar

Artery Occlusion

Page

http://dx.doi.org/10.1212/ WNL.0000000000012858

Dr. Sang and associates looked at how well people recovered after treatment for a stroke due to a blockage in the basilar artery. The basilar artery is critical to the brain because it brings blood to deep brain structures like the brainstem, which is important in controlling involuntary body functions such as breathing. The treatment they studied is called endovascular therapy (EVT). More specifically, they looked at time to treatment (which they measured as onset to puncture time [OPT]). In other words, once the stroke had occurred, they looked at the connection between when the treatment was given and how well the person recovered.

\section{How Was the Study Done?}

This study was done in China. Forty-seven stroke centers collected information from January 2014 to May 2019. The researchers identified 829 people who had had a basilar artery stroke. Of these, there were 639 patients whose basilar artery stroke was treated with EVT (that is, therapy that is performed inside the affected blood vessel). The study carefully evaluated these patients, looking at 2 endpoints. First, the authors measured how well the person was doing 90 days after the stroke. They used the Rankin Scale, a commonly used scale that measures the degree of disability in people who have had a stroke or who have a neurologic disability. In addition, they looked at the person's functional independence following the stroke.

The authors divided the group into 4 smaller groups. The groups were categorized by the amount of time that had passed between the onset of each person's stroke and the time they had received treatment (in this case, the time to EVT). The treatment groups were those who had treatment less than 4 hours, 4-8 hours, 8-12 hours, and more than 12 hours after stroke. As a control, the researchers compared the group of people with EVT against those who were treated with medicines alone. 


\section{What Did They Find?}

First, the researchers observed that basilar artery stroke was often very serious: $46 \%$ of the patients whose data the researchers studied had died less than 90 days after their stroke. A total of $7.2 \%$ of people who had received EVT developed bleeding in the brain (called a hemorrhage) within 48 hours of the therapy. Of the people who had bleeding, the majority were treated with EVT more than 4 hours after their stroke. Those who had EVT less than 4 hours after their stroke were unlikely to develop bleeding in the brain. In other words, a longer time to treatment seems to have correlated with a higher risk of bleeding.

Of the patients who survived their stroke, $32.2 \%$ had a favorable outcome, and $27.5 \%$ regained functional independence. Those who received treatment more quickly (less than 4 hours after their stroke) had better outcomes overall than those who were treated later (more than 4 hours after their stroke). The researchers found that time was an important factor in the endovascular treatment of basilar artery stroke. The longer it took to get to treatment, the worse a person was likely to do. When the researchers looked at the results, they found there was a point of diminishing returns. There was a loss of the benefits of EVT in people who were treated more than 9 hours after their stroke. However, that does not mean that everyone treated more than 9 hours after their stroke did poorly. Some people who received EVT 9 hours or more after basilar artery stroke did well. These people were more likely to have had a smaller, less debilitating stroke than those who did poorly.

\section{What Does This Mean?}

Many trials in stroke treatments have shown that "time is brain." This means that every minute counts when it comes to stroke treatment. The longer it takes to reach treatment, the greater the degree of neurologic injury is likely to be. In this study, the authors found the same result. In fact, they estimated that the chance of a favorable outcome decreased by $2.3 \%$ for every hour treatment was delayed. In addition, the chance of dying as a result of the stroke increased by $2.0 \%$ for every hour that the EVT was delayed. In short, the quicker a stroke is diagnosed and treated, the better recovery typically goes, and the more likely the person is to have a greater return of neurologic function. 


\section{About Stroke and the Brain}

\section{How Does the Brain Work?}

For many years, I have tried to think of a way to explain how the brain works. To me, it seems the brain is most akin to an orchestra. There are many parts to an orchestra: percussion, wind instruments, string instruments, et cetera. Each instrument has a part to play in the overall, more complex musical story. When playing together, which requires that the musicians listen to one another, the orchestra can perform complex, beautiful music. The brain is just like this. It is divided into sections like language, movement, and sensation. The difference is that the brain is much more complex than an orchestra. A philharmonic may have 150 members. The brain contains billions of neurons.

Suppose that while the musicians are playing, someone suddenly turned out the lights on one section of the "brain's orchestra." These players would not be able to see the music they were playing. The rest of the orchestra would continue to play without them. If the section that was no longer playing was "language," the person would suddenly be unable to speak (or perhaps to understand spoken or written words). This is what happens during a stroke. However, in a stroke, the musician brain cells die, and cannot begin to play again. Since we do not have a way to rejuvenate or regrow brain cells after a stroke, treatments have been aimed at stroke prevention, restoring blood flow to an area of stroke (tissue plasminogen activator [tPA] therapy), and endovascular treatments. Other therapies try to accelerate or improve how the brain recovers function after a stroke. This would be the same as retraining the remaining orchestra members so they could take over the parts that had been played by the lost musicians.

\section{What Is Stroke?}

Stroke is a sudden neurologic event. ${ }^{2,3}$ There are several symptoms common to most strokes. In fact, the American Stroke Association uses a very simple strategy called FAST: $F=$ face drooping, $A=$ arm weakness,$S=$ speech difficulty, and $T=$ time to call 911. There are other signs of stroke such as sudden numbness, sudden confusion, difficulty seeing, or trouble walking. Any of these could be a sign of stroke, but regardless of the symptom, it is always sudden.

\section{What Are the Types of Stroke, and How Are They Treated?}

There are 2 main types of stroke: ischemic and hemorrhagic. Ischemic strokes account for about $87 \%$ of strokes. Ischemic strokes are usually caused by blood clots that block an artery in the brain. Because blood cannot get past the blockage, neither can oxygen. The brain cells that rely on this oxygen start to have problems, and may die. Time is critical: the longer the cells lack oxygen, the greater number of cells that die.

There are many treatments that are designed to break up the blockage causing the stroke. One of them is tPA; when given intravenously within a short time after the ischemic stroke, tPA dissolves the clot that is blocking the artery. This reopens the blood vessel, restoring blood flow and oxygen to the brain. Another treatment option is EVT. There are several kinds of EVT. All of them approach the clot from within the blood vessel. One type is called mechanical thrombectomy. This is when a medical device is inserted into the affected artery and is sent directly to the clot. It removes the clot, restoring blood flow to the brain. In another type, a device called a stent is placed inside the blood vessel, basically shoving the clot off to the side of the blood vessel so blood flow can resume. The effects of EVT treatments are rapid and can result in a reversal of the neurologic damage.

In the second type of stroke, hemorrhagic stroke, bleeding occurs in the brain. This could be caused by a weak blood vessel or possibly an aneurysm that has ruptured. One of the most common causes of hemorrhagic stroke is poorly managed high blood pressure. The constant high blood pressure puts too much strain on the blood vessels, causing them to burst. Often, surgery is needed to either remove or repair the damaged blood vessel.

Most treatments for stroke are designed to prevent the problem from occurring in the first place. Common causes of stroke include high blood pressure, cigarette smoking, diabetes, obesity, and eating a high-fat diet. Preventing stroke for some people may be a matter of improving their diet: eating healthier foods and avoiding foods that contain high fat or high cholesterol. For others, preventing stroke may include good, consistent control of blood pressure or diabetes. Cigarette smoking should be stopped or be avoided altogether. Physical inactivity is also a risk factor, excluding vigorous activity immediately following stroke. Studies have shown the long-term benefits of exercise over and over again. The bottom line: the more we move and exercise, the healthier we are.

\section{For More Information}

Brain \& Life

brainandlife.org

\section{American Stroke Association}

stroke.org

\section{Brain Aneurysm Foundation}

bafound.org

\section{References}

1. Sang HF, Yuan J, Qiu ZM, et al. Association between time to endovascular therapy and outcomes in patients with acute basilar artery occlusion. Neurology. 2021;97(22):e2152-e2163.

2. American Heart Association web site. Accessed December 2020. heart.org/

3. American Stroke Association web site. Accessed December 2020. stroke.org/ 


\title{
Neurology
}

\author{
Treating Stroke From Inside the Blood Vessel: Time Matters \\ Steven Karceski \\ Neurology 2021;97;e2250-e2252 \\ DOI 10.1212/WNL.0000000000012920
}

This information is current as of November 29, 2021

\begin{tabular}{|c|c|}
\hline $\begin{array}{l}\text { Updated Information \& } \\
\text { Services }\end{array}$ & $\begin{array}{l}\text { including high resolution figures, can be found at: } \\
\text { http://n.neurology.org/content/97/22/e2250.full }\end{array}$ \\
\hline References & $\begin{array}{l}\text { This article cites } 1 \text { articles, } 1 \text { of which you can access for free at: } \\
\text { http://n.neurology.org/content/97/22/e2250. full\#ref-list-1 }\end{array}$ \\
\hline Citations & $\begin{array}{l}\text { This article has been cited by } 2 \text { HighWire-hosted articles: } \\
\text { http://n.neurology.org/content/97/22/e2250.full\#\#therarticles }\end{array}$ \\
\hline Subspecialty Collections & $\begin{array}{l}\text { This article, along with others on similar topics, appears in the } \\
\text { following collection(s): } \\
\text { Autonomic diseases } \\
\text { http://n.neurology.org/cgi/collection/autonomic_diseases }\end{array}$ \\
\hline Permissions \& Licensing & $\begin{array}{l}\text { Information about reproducing this article in parts (figures,tables) or in } \\
\text { its entirety can be found online at: } \\
\text { http://www.neurology.org/about/about_the_journal\#permissions }\end{array}$ \\
\hline Reprints & $\begin{array}{l}\text { Information about ordering reprints can be found online: } \\
\text { http://n.neurology.org/subscribers/advertise }\end{array}$ \\
\hline
\end{tabular}

Neurology ${ }^{\circledR}$ is the official journal of the American Academy of Neurology. Published continuously since 1951, it is now a weekly with 48 issues per year. Copyright (C 2021 American Academy of Neurology. All rights reserved. Print ISSN: 0028-3878. Online ISSN: 1526-632X.

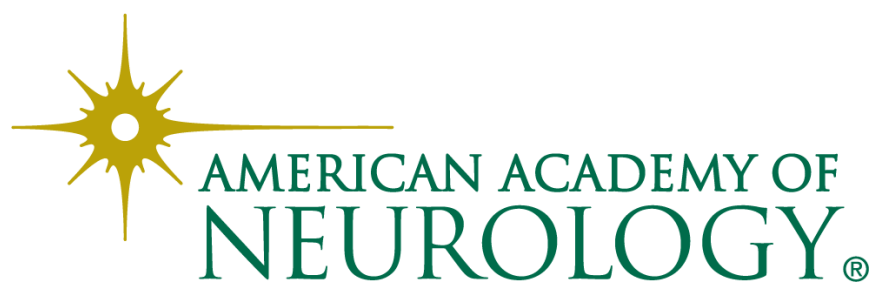

